\title{
PENGARUH CITRA MEREK TERHADAP KEPUTUSAN PEMBELIAN MOBIL TOYOTA AVANZA PADA AUTO 2000 CABANG ASIA AFRIKA BANDUNG
}

\author{
Yayan Sofyan \\ Yeni Andriyani \\ STIE Muhammadiyah Bandung \\ Jl. Karapitan No.143 Bandung \\ Email :yayan.sofyan@stiemb.ac.id
}

\begin{abstract}
Abstrak
Keputusan untuk membeli suatu produk sangat dipengaruhi oleh penilaian akan bentuk kualitas produk tersebut. Tuntutan permintaan akan sebuah produk barang yang semakin berkualitas membuat perusahaan yang bergerak diberbagai bidang usaha berlomba-lomba meningkatkan kualitas produk yang mereka miliki demi mepertahankan Brand Image (citra merek) produk yang mereka miliki. Merek mempunyai sifat khas, dan sifat khas inilah yang membedakan produk yang satu berbeda dengan produk yang lainnya.Salah satu industri yang tumbuh pesat sampai saat ini adalah industri otomotif, perkembangannya ditunjang dengan bertambah luasnya sarana jalan, peningkatan pendapatan masyarakat yang meningkat menempatkan mobil bukan lagi untuk golongan menengah keatas.Kenyataan ini merupakan peluang yang dimanfaatkan oleh produsen mobil dengan mengeluarkan berbagai jenis dan merek yang dikeluarkan di Indonesia.dengan sendirinya kendaraan yang dipasarkan mampu menarik minat konsumen.

Penelitian ini dilaksanakan di Auto 2000 Cabang Bandung.Model penelitian yang digunakan yakni dengan metode deskriptif dengan melakukan observasi, wawancara, kuesioner dan studi kepustakaan yang dilakukan secara sistematik berdasarkan tujuan penelitian. Metode analisis yang digunakan adalah dengan metode analisis regresi linear sederhana, dengan menggunakan uji hipotesis yaitu uji t. Kemudian menggunakan perhitungan korelasi untuk mengetahui seberapa besar pengaruh dan signifikansi citra merek (brand image)terhadap pengambilan keputusan pembelian mobil Toyota Avanza pada Auto 2000 Cabang Bandung.

Dari hasil penelitian diketahui bahwa seluruh item pertanyaanmenunjukkan hasil yang valid dimana semua nilai $\mathrm{R}$ kritis-nya berada di atas nilai titik kritis yaitu $>0.273$. Sedangkan hasil uji reliabilitas pada variabel tersebut menunjukkan hasil yang reliabel dimana semua nilai $\mathrm{R}$ kritis-nya berada di atas nilai titik kritis yaitu $>0.600$ dengan rincian : $\mathrm{R}$ kritis variabel citra merek sebesar 0.927 serta $\mathrm{R}$ kritis variabel keputusan pembelian sebesar 0.722.Koefisien determinasi merupakan koefisien yang digunakan untuk mengetahui besarnya kontribusi variabel citra merek terhadap perubahan variabel keputusan pembelian,
\end{abstract}


sesuai dengan hasil perhitungan diperoleh $85,4 \%$ dengan demikian kontribusi 14,6\% merupakan kontribusi variabel lain yang tidak diteliti.

Citra merek Mobil Toyota Kijang Avanza Pada Auto 2000 Cabang Bandung cukup baik menurut baik menurut persepsi konsumen. Adapun keputusan pembelian Mobil Toyota Avanza pada Auto 2000 Cabang Bandung cukup baik menurut persepsi konsumenCitra merek berpengaruh signifikan terhadap keputusan pembelian Mobil Toyota Avanza pada Auto 2000 Cabang Bandung.

Kata kunci : Citra Merek dan Keputusan Pembelian

\section{PENDAHULUAN}

Dalam perkembangan ekonomi sekarang ini, Setiap perusahaan industri maupun usaha jasa dituntut untuk dapat bersaing dengan strategi pemasaran yang baik dalam memasarkan produknya, tentunya bertujuan untuk mencapai peningkatan keuntungan melalui volume penjualan. Artinya laba itu dapat diperoleh dengan melalui cara pada pemuasan konsumen.

Konsumen saat ini pandai dalam memilih suatu produk, sampai pada keputusan untuk membeli produk tersebut.Seperti yang kita ketahui bersama bahwa tawaran produk saat ini sangatlah beragam dan banyak, tak terkecuali untuk produk yang mana sekarang ini mengalami perkembangan yang sangat pesat. Pilihan yang semakin banyak ini membuat banyak konsumen dapat menentukann pilihannya akan suatu produk.

Keputusan untuk membeli suatu produk sangat dipengaruhi oleh penilaian akan bentuk kualitas produk tersebut. Tuntutan permintaan akan sebuah produk barang yang semakin berkualitas membuat perusahaan yang bergerak diberbagai bidang usaha berlomba-lomba meningkatkan kualitas produk yang mereka miliki demi mepertahankan Brand Image (citra merek) produk yang mereka miliki. Merek mempunyai sifat khas, dan sifat khas inilah yang membedakan produk yang satu berbeda dengan produk yang lainnya. Menurut UU Merek No.15 Tahun 2001 Pasal 1 Ayat 1: Merek adalah tanda yang berupa gambar, nama kata, huruf-huruf, angka-angka, susunan warna atau kombinasi dari unsur-unsur tersebut yang memiliki daya pembeda dan digunakan dalam kegiatan perdagangan barang dan jasa.

Berbagai upaya dilakukan perusahaan dalam rangka mempertahankan Brand Image yang mereka miliki di antaranya inovasi teknologi keunggulan yang dimiliki produk tersebut, penetapan harga yang bersaing dan promosi yang tepat sasaran. Semakin baik Brand Image produk yang dijual maka akan berdampak pada keputusan pembelian oleh konsumen.

Keputusan pembelian oleh konsumen adalah keputusan yang melibatkan persepsi terhadap kualitas, nilai dan harga.Konsumen tidak hanya menggunakan harga sebagai indikator kualitas tetapi juga sebagai indikator biaya yang dikorbankan untuk ditukar dengan produk atau manfaat produk.Disinilah kita melihat sejauh mana merek dapat memengaruhi penilaian konsumen dengan Brand Image (Citra Merek) dari produk tersebut. 
Salah satu industri yang tumbuh pesat sampai saat ini adalah industri otomotif, perkembangannya ditunjang dengan bertambah luasnya sarana jalan, peningkatan pendapatan masyarakat yang meningkat menempatkan mobil bukan lagi untuk golongan menengah keatas.Kenyataan ini merupakan peluang yang dimanfaatkan oleh produsen mobil dengan mengeluarkan berbagai jenis dan merek yang dikeluarkan di Indonesia.dengan sendirinya kendaraan yang dipasarkan mampu menarik minat konsumen.

Saat ini pasar mobil indonesia di dominasi oleh mobil serba guna alias MPV (Multi Purpose Vehicle). Total MPV untuk semua segmen tahun lalu penjualannya mencapai 348.670 atau memperoleh porsi 45,5

persen, pangsa pasar kedua adalah SUV dengan total penjualan 85.289 unit atau 11,1 persen, berikutnya kendaraan komersial, yaitu truk 2-ton (CV2T,4 dan 6 roda) dengan penjualan 83.984 unit 10,9 persen, sedangkan mobil kompak atau hatcback, 77.295 unit 10,1 persen, khusus sedan, (sebagian besar taksi) terjual 33.146 unit atau 4,3 persen. Sesuai data terakhir yang diperoleh KOMPAS.com dari anggota Gabungan Industri Kendaraan Bermotor Indonesia (GAIKINDO, 2014)

Salah satu survei merek di Indonesia yang dijadikan sebagai indikator kinerja sebuah merek adalah Top Brand Award. Survei ini dipelopori oleh majalah "MARKETING" yang bekerja sama dengan lembaga survei Frontier Consulting Group. Konsep tentang Top Brand mengenai merek suatu produk didasarkan pada tiga parameter yaitu: merek yang paling diingat (top of mind), merek yang terakhir kali dibeli atau dikonsumsi (last used), serta merek yang akan dipilih kembali di masa mendatang (future intention). Ketiga parameter tersebut diformulasikan dengan cara menghitung rata-rata terboboti masingmasing parameter untuk membentuk Top Brand Index (TBI). Kriteria yang harus dipenuhi agar sebuah merek berhak menyandang predikat Top Brand adalah memperoleh Top Brand Index minimum sebesar $10 \%$ dan berada dalam posisi top three di dalam kategori produknya.Dengan adanya dua kriteria tersebut tidak menutup kemungkinan dalam satu kategori produk terdapat lebih dari satu merek maksimal tiga merek yang meraih predikat Top Brand.

Produk industri otomotif sangat kompetitif dalam bentuk, warna, kecanggihan teknologi, dan merek. Merek-merek mobil yang ada dipasaran otomotif di Indonesia sekarang ini berasal dari buatan Eropa dan Asia seperti Mitsubishi, KIA, Honda, Daihatsu,Suzuki, Ford, Proton, Nissan, Hyundai, dan Toyota yang banyak diminati oleh masyarakat Indonesia. setiap merek produk menawarkan pelayanan tersendiri untuk pelanggannya, berupa layanan purna jual, servis, suku cadang, sampai penetapan harga yang cukup bersaing sesuai dengan jenis dan segmen pasarnya.

Tabel 1.Data Volume Penjualan Mobil tahun 2014-2015 Nasional

\begin{tabular}{|l|c|}
\hline \multicolumn{1}{|c|}{ Jenis Kendaraan } & Jumlah Unit \\
\hline Toyota Avanza & 14.118 \\
\hline Honda Mobilio & 7.526 \\
\hline Toyota Agya & 6.221 \\
\hline Toyota Kijang Innova & 5.396 \\
\hline Daihatsu Gran Max P/U & 4.341 \\
\hline
\end{tabular}




\begin{tabular}{|l|l|}
\hline Sujuki Carry P/U & 4.101 \\
\hline Sujuki Ertiga & 4.079 \\
\hline Daihatsu Ayla & 4.032 \\
\hline Daihatsu Xenia & 3.543 \\
\hline Toyota Yaris & 3.054 \\
\hline Toyota Rush & 2.747 \\
\hline Mitsubishi T-120 SS mini P/U & 2.408 \\
\hline Mitsubishi L-300 P/U diesel & 2.407 \\
\hline Toyota Fortuner & 2.330 \\
\hline Sujuki Karimun Wagon R & 2.172 \\
\hline Daihatsu Terios & 1.889 \\
\hline Sujuki Apv pikap & 1.706 \\
\hline Nissan Grand Livina & 1.393 \\
\hline Honda Brio Satya & 1.224 \\
\hline Honda Jazz & 1.213 \\
\hline
\end{tabular}

Sumber :Gaikindo 2015

Berdasarkan data Gabungan Industri Kendaraan Bermotor Indonesia (Gaikindo) total penjualan kendaraan tahun 2015 mencapai angka 1.208.019 unit. Toyota Avanza menjadi pemimpin tertinggi dengan total penjualan 14.118 unit.

Auto 2000, sebagai dealer Toyota mencoba memberikan suatu pelayanan yang telah digariskan oleh Toyota, sehingga membentuk suatu produk yang berkualitas, bukan hanya dari segi pelayanan tetapi secara keseluruhan.Produk mobil merek Toyota yang dipasarkan oleh Auto 2000 memiliki kelebihan dan ciri khas tersendiri dibandingkan dengan kendaraan jenis lain. Minat masyarakat dalam menggunakan kendaraan khususnya merek Toyota inilah yang memancing para dealer penyedia produk mobil berlomba-lomba menghasilkan produk berkualitas yang diminati konsumen dengan berbagai keunggulan produknya masingmasing.Hal ini telah menjadi kebijaksanaan pemasaran perusahaan dengan harapan produk yang dipasarkan dapat menembus pasar, serta mampu meraih pangsa pasar yang luas.
Untuk itu, maka tujuan untuk meningkatkan produk tertutama bentuk, tipe, serta daya tahan, dan merek yang dipasarkan harus dapat meningkatkan kepuasan bagi konsumen. Kebijakan produk juga dilakukan dalam menghadapi kejenuhan dari suatu jenis maupun tipe produk dan olehnya itu diadakan pembaharuan model, maupun kapasitas yang dimiliki jenis produk tersebut.

Auto 2000 sebagai agen tunggal penjualan merek mobil Toyota berdasarkan data penjualan selama ini senantiasa menduduki peringkat pertama dalam penjualan mobil dibanding merek lain yang dipegang oleh distributor yang lain. Toyota menguasai pangsa pasar sebesar $45 \%$ (menduduki peringkat pertama).Sisa dari persentase tersebut terdistribusi hampir merata terhadap belasan merek mobil lainnya.Tercatat beberapa kali Auto 2000 mendapatkan penghargaan utnuk penjualan tertinggi di Indonesia, suatu prestasi yang sangat membanggakan. Berikut data yang penulis lampirkan dari Perusahaan Otomotif Auto 2000 Bandung.

Tabel 2.Data Volume Penjualan Mobil Toyota Avanza pada Auto 2000 Bandung(Unit) 


\begin{tabular}{|l|c|c|}
\hline Jenis Mobil & $\mathbf{2 0 1 4}$ & $\mathbf{2 0 1 5}$ \\
\hline Avanza & 98 & 57 \\
\hline Innova & 76 & 63 \\
\hline Yarris & 70 & 59 \\
\hline Rush & 67 & 53 \\
\hline Fortunner & 62 & 44 \\
\hline Agya & 58 & 38 \\
\hline Vios & 54 & 26 \\
\hline Camry & 43 & 28 \\
\hline Corolla Altis & 32 & 21 \\
\hline Alphard & 21 & 14 \\
\hline Etios & 15 & 9 \\
\hline Hilux & 11 & 4 \\
\hline Land Cruiser & 5 & 7 \\
\hline
\end{tabular}

: Auto 2000 Asia Afrika Bandung

Berdasarkan Table diatas dapat kita lihat bahwa penjualan Toyota Avanza merupakan mobil yang paling diminati meskipun mengalami penurunan penjualan, diikuti oleh Kijang Innova dan Toyota Yarris dibelakangnya.

\section{KERANGKA TEORITIS HIPOTESIS}

\section{Keputusan Pembelian}

Keputusan adalah suatu pemilihan tindakan dari dua atau lebih pilihan alternative. Dengan kata lain, orang yang mengambil keputusan harus mempunyai satu pilihan dari beberapa alternative yang ada. Bila seseorang dihadapkan pada dua pilihan, yaitu membeli dan tidak membeli dan kemudian dia memilih membeli maka dia ada dalam posisi membuat suatu keputusan semua orang mengambil keputusan setiap hari dalam hidupnya.Hanya saja keputusan yang diambil kadang-kadang tidak mereka sadari Ristianti dan John (2005:226).

Sutisna (2002:15) menyebutkan bahwa pengambilan keputusan oleh konsumen untuk melakukan pembelian suatu produk diawali oleh adanya kesadaran atas pemenuhan kebutuhan dan dan keinginan yang disebut need arousal.Kebanyakan penulis menyatakan tahap ini sebagai tahap menyadari adanya masalah (problem recognition). Selanjutnya jika sudah disadari adanya kebutuhan dan keinginan, maka konsumen akan mencari informasi mengenai keberadaan produk yang diinginkannya. Proses pencarian informasi ini akan dilakukan dengan mengumpulkan semua informasi yang berhubungan dengan produk yang diinginkannya.

Bila ditinjau dari alternative yang harus dicari sebetulnya dalam proses pengambilan keputusan, konsumen harus melakukan pemecahan masalah. Masalah itu timbul dari kebutuhan yang dirasakan dan keinginannya untuk memenuhi kebutuhan itu dengan konsumsi produk atau jasa yang sesuai. Menurut Ristiyanti dan John (2005:226) pemecahan masalah ini memiliki 3 tingkatan yaitu :

- Pemecahan masalah yang mensyaratkan respon yang rutin

- Pemecahan masalah dengan proses yang tidak berbelit-belit (terbatas)

- Pemecahan masalah yang dilakukan dengan upaya yang lebih berhati-hati dan penuh pertimbangan (pemecahan masalah yang intensif)

Gambar berikut ini menguraikan tipe atau tingkatan pemecahan masalah yang dilakukan oleh konsumen 


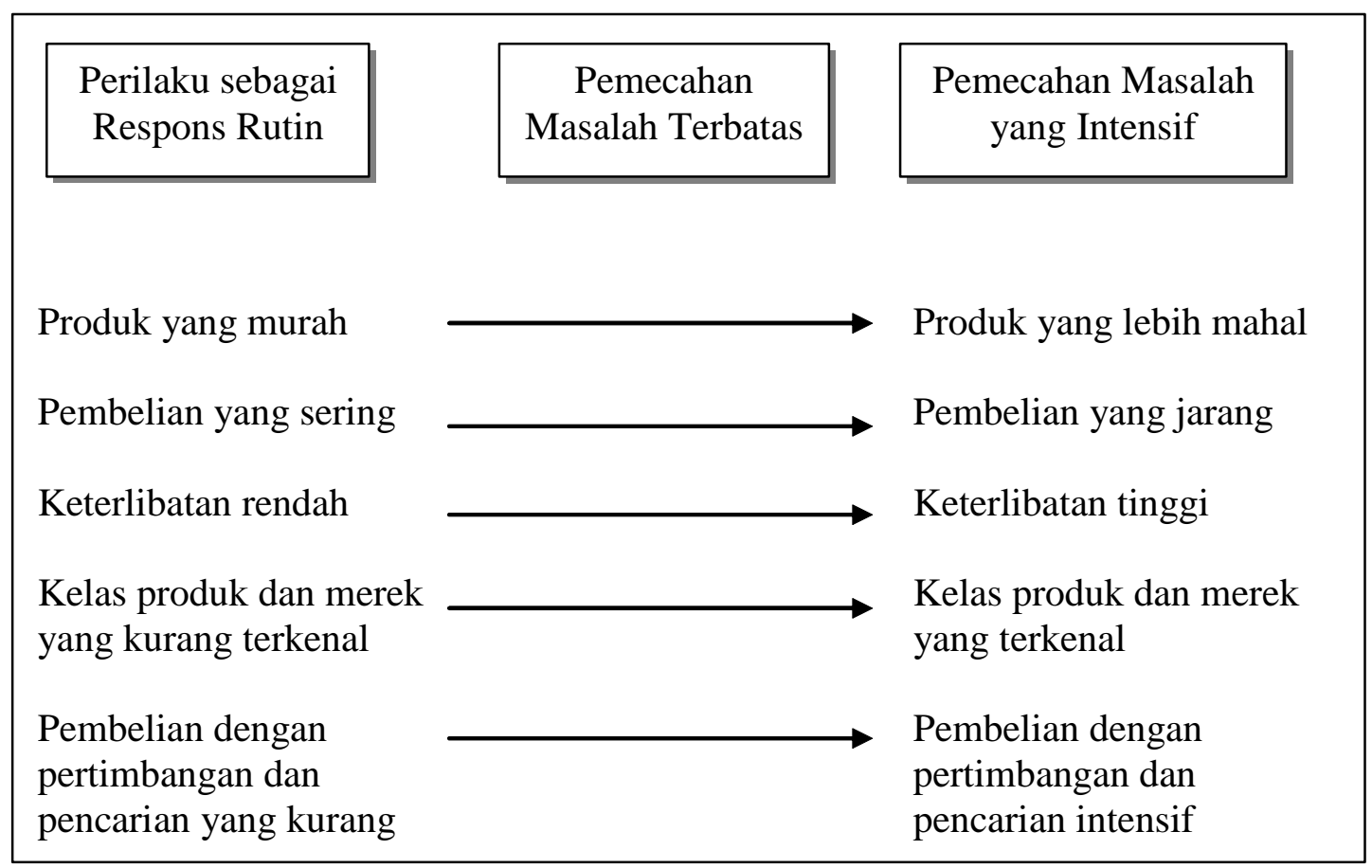

\section{Gambar 1.Tingkat-tingkat Pemecahan Masalah Konsumen Sumber :Ristiyanti dan John (2005:228)}

Menurut Herry Achmad (2010:64) keputusan pembelian adalah penilaian terhadap keputusan membeli didahului oleh maksud keputusan membeli, artinya apa yang menyebabkan maksud untuk membeli tersebut.

Ada 2 faktor penyebabnya, yaitu :

1. Sikap orang lain : keputusan membeli itu banyak dipengaruhi oleh teman-teman, tetangga, atau siapa saja yang ia percaya.

2. Faktor-faktor situasi yang tidak terduga : yaitu faktor harga, pendapatan keluarga, dan keuntungan yang diharapkan dari produk tersebut.

Menurut Ristiyanti dan John (2005:228) ada empat sudut pandang dalam menganalisis pengambilan keputusan konsumen.Pertama adalah sudut pandang ekonomis, dan kedua adalah sudut pandang pasif.Sudut pandang ketiga adalah sudut pandang kognitif dan yang terakhir adalah sudut pandang emosional.

1) Sudut Pandang Ekonomis

Pandangan ini melihat konsumen sebagai orang yang membuat keputusan secara rasional.Ini berarti bahwa konsumen harus mengetahui semua alternative produk yang tersedia dan harus mampu membuat peringkat dari setiap alternative yang ditentukan, dilihat dari kegunaan dan kerugiannya serta harus dapat mengidentifikasi satu alternative yang terbaik.Menurut para ahli ilmu social, model economic man ini tidak realistis. Alasan yang mereka kemukakan adalah :

- Manusia memiliki keterbatasan kemampuan, kebiasaan dan gerak. Orang yang tidak terampil 
berkomunikasi akan malas bertanya. Orang yang tidak suka pergi jauh, membeli di warung sebelah rumah.

- Manusia dibatasi oleh nilai-nilai dan tujuan. Seseorang yang ingin menghangatkan badan di malam hari yang dingin, tidak selalu pergi membeli ronde ke kota. Alasan pertama karena dia perempuan dan perempuan tidak pantas pergi malam-malam di negeri ini; karena tujuannya hanya menghangatkan badan. Jadi, kopi panas buatan sendiri pun bisa memenuhi tujuan.

- Manusia dibatasi oleh pengetahuan yang mereka miliki. Tidak semua informasi mengenai produk bisa mereka pahami. Jadi, criteria evaluasi yang ingin mereka bentuk pun tidak akan setepat economic man.

Sehubungan dengan itu, konsumen tidak membuat keputusan yang rasional, tetapi keputusan yang memuaskan adalah keputusan yang cukup baik.

2) Sudut Pandang Pasif

Sudut pandang ini berlawanan dengan sudut pandang ekonomis.Pandangan ini mengatakan bahwa konsumen pada dasarnya pasrah kepada kepentingannya sendiri dan menerima secara pasif usahausaha promosi dari para pemasar.Kenyataannya, bentukbentuk promosi yang dilakukan pemasar juga mengenai sasaran.Konsumen dianggap sebagai pembeli yang impulsive dan irasional. Kelemahan pandangan ini adalah bahwa pandangan ini tidak mempertimbangkan kenyataan bahwa konsumen memainkan peranan penting dalam setiap pembelian yang mereka lakukan, baik dalam hal mencari informasi tentang berbagai alternative produk, maupun dalam menyeleksi produk yang dianggap akan memberikan kepuasan terbesar.

3) Sudut Pandang Kognitif

Sudut pandang ini menganggap konsumen sebagai cognitive man atau sebagai problem solver.Menurut pandangan ini, konsumen merupakan pengolah informasi yang senantiasa mencari dan mengevaluasi informasi tentang produk dan gerai.Pengolahan informasi selalu berujung pada pembentukan pilihan, selanjutnya terjadi inisiatif untuk membeli atau menolak produk.Jadi cognitive man dapat diibaratkan berdiri di antara economic man dan passive man.Cognitive man juga seringkali mempunyai pola respons tertentu terhadap informasi yang berlebihan dan seringkali pula mengambil jalan pintas untuk memfasilitasi pengambilan keputusannya (heuristic) untuk sampai pada keputusan yang memuaskan. Seseorang yang menginginkan parfum untuk memenuhi kebutuhan sosialisasinya akan mencari informasi sebanyak mungkin dan menentukan alternative, tetapi bisa saja dia menentukan pilihan berdasarkan harga.

4) Sudut pandang Emosional Pandangan ini menekankan emosi sebagai pendorong utama sehingga konsumen membeli 
suatu produk.Favoritisme merupakan salah satu bukti bahwa seseorang berusaha mendapatkan produk favoritnya, apa pun yang terjadi. Benda-benda yang menimbulkan kenangan juga dibeli berdasarkan emosi.Orang suka sekali membeli stiker sepak bola, kartu baseball, dsb, dengan harga tidak murah, karena didorong oleh emosi belaka.

Jadi, perasaan dan suasana hati sangat berperan dalam pembelian yang emosional.Dekorasi gerai, cahaya, warna, aroma, music dsb dipakai pemasar untuk mempengaruhi perasaan dan suasana hati. Tetapi jangan sampai terperangkap pada anggapan bahwa emotional man itu tidak rasional. Mendapatkan produk yang membuat perasaannya lebih baik merupakan keputusan yang rasional.

5) Input

Kompenen input merupakan pengaruh-pengaruh eksternal sebagai sumber informasi tentang produk tertentu dan mempengaruhi nilai yang berhubungan dengan produk, sikap, dan perilaku konsumen. Input yang utama adalah kegiatan-kegiatan bauran pemasaran dan pengaruhpengaruh sosial budaya. Ristiyanti dan John (2005:231)

- Input Pemasaran :

Aktifitas-aktifitas pemasaran merupakan usaha-usaha langsung untuk menjangkau, menginformasikan dan membujuk konsumen agar membeli dan menggunakan produk tertentu.Usaha-usaha tersebut meliputi empat "P" atau bauran pemasaran, yaitu Product, Price, Place, Promotion.

- Pengaruh sosial budaya :

Lingkungan sosial budaya yang dimaksud antara lain : Keluarga, sumber informal, sumber non komersial, kelas sosial, budaya dan sub budaya.

6) Proses

Komponen

memperhatikan

proses konsumen membuat keputusankeputusan. Untuk dapat mengerti proses, harus dipahami beberapa konsepsi psikologi terkait. Area psikologis adalah pengaruhpengaruh internal yang mempengaruhi proses pengambilan keputusan konsumen. Pengaruhpengaruh internal tersebut adalah motivasi, persepsi, pembelajaran, kepribadian dan sikap. Proses pengambilan keputusan oleh seorang konsumen terdiri dari 3 tahapan yaitu : pengenalan kebutuhan, pencarian pra beli, serta evaluasi terhadap alternative Ristiyanti dan John (2005:233)

7) Output

Komponen output menunjuk kepada dua macam kegiatan pasca keputusan yang saling berhubungan erat yaitu :

○ Perilaku beli

- Evaluasi pasca beli

Faktor lain yang tidak kalah penting dalam mempengaruhi proses pengambilan keputusan konsumen yaitu faktor situasi. Situasi dapat menjadi perubah dalam proses pengambilan keputusan konsumen Ristiyanti dan John (2005:234).

Jenis-jenis situasi yang dapat menjadi perubah adalah :

○ Situasi Komunikasi 
- Situasi Pembelian

- Situasi Penggunaan

- Situasi Penyingkiran Produk

Klasifikasi situasional yaitu :

$\bigcirc$ Lingkungan Fisik

- Lingkungan Sosial

- Lingkungan Waktu

- Tujuan Pembelian dan Konsumsi

- Mood (suasana hati) dan Kondisi Sementara saat Pembelian

- Situasi Ritual

Seperti pengambilan keputusan dalam kehidupan sehari-hari dan kehidupan berorganisasi, keputusan beli pun ditentukan dengan cara memilih tindakan dari dua alternaltif pilihan atau lebih. Sejauh mana konsumen memiliki alternative, tergantung pada sifat pembeliannya pada pembelian rutin, alternative tidak penting lagi, sedangkan dalam pembelian dengan keterlibatan tinggi, konsumen sangat memerlukan informasi untuk mengembangkan alternative.Ada empat pandangan dalam pengambilan keputusan konsumen.Pertama, adalah sudut pandang ekonomis, kedua, sudut pandang pasif, kemudian sudut pandang kognitif, terakhir sudut pandang emosional. Masing-masing memiliki alasan yang berbeda satu sama lain tentang bagaimana seseorang mengambil keputusan.

Menurut Kotler dan Keller (2009:188) dalam tahap evaluasi, konsumen membentuk referensi antar merek dalam kumpulan pilihan.Konsumen mungkin juga membentuk maksud untuk membeli merek yang paling disukai. Dalam melaksanakan maksud pembelian, konsumen dapat membentuk lima sub keputusan : merek, penyalur, kuantitas, waktu, dan metode pembayaran.

Dalam Kotler (2009:184-185) disebutkan bahwa proses psikologis dasar memainkan peranan penting dalam memahami bagaimana konsumen benar-benar membuat keputusan pembelian mereka. Periset pemasaran telah mengembangkan "model tingkat" proses keputusan pembelian. Konsumen melalui 5 tahap pengenalan masalah, pencarian informasi, evaluasi alternative, keputusan pembelian, dan perilaku pasca pembelian.Jelas, proses pembelian dimulai jauh sebelum pembelian actual dan mempunyai konsekuensi dalam waktu lama setelahnya. Proses pembelian dimulai ketika pembeli menyadari suatu masalah atau kebutuhan yank dipicu oleh rangsangan internal atau eksternal. Dengan rangsangan internal, salah satu dari kebutuhan normal seseorang-rasa lapar, haus, seks- naik ketingkat maksimum dan menjadi dorongan atau kebutuhan bisa timbul akibat rangsangan eksternal. Seseorang mungkin mengagumi mobil baru tetangga atau melihat iklan televise untuk liburan ke hawai, yang memicu pemikiran tentang kemungkinan melakukan pembelian. Pemasar harus mengidentifikasi keadaan yang memicu kebutuhan tertentu dengan mengumpulkan informasi dari sejumlah konsumen.Lalu mereka dapat mengembangkan strategi pemasaran yang memicu minat kosumen.Terutama untuk pembelian fleksibel seperti barang-barang mewah, paket liburan, dan pilihan hiburan, pemasar mungkin harus meningkatkan motivasi konsumen sehingga pembelian potensial mendapat pertimbangan serius.Ternyata konsumen sering 
mencari jumlah informasi yang terbatas.Survei memperlihatkan bahwa untuk barang tahan lama setengah dari semua konsumen hanya melihat satu toko, dan hanya 30\% yang melihat lebih dari satu merek peralatan.Kita dapat membedakan antara 2 tingkat keterlibatan dengan pencarian.Keadaan pencarian yang lebih rendah disebut perhatian tajam.Pada tingkat ini seseorang hanya menjadi lebih reseptif terhadap informasi tentang sebuah produk. Pada tingkat berikutnya, seseorang dapat memasuki pencarian informasi

Mencari bahan bacaan, menelepon teman, melakukan kegiatan online, dan mengunjungi toko untuk mempelajari produk tersebut.

Sumber informasi utama dimana konsumen dibagi menjadi 4 kelompok :

- Pribadi. Keluarga, teman, tetangga, rekan.

- Komersial. Iklan, situs web, wiraniaga, penyalur, kemasan, tampilan.

- Publik. Media massa, organisasi pemeringkat konsumen.

- Eksperimental. Penanganan, pemeriksaan, penggunaan produk.

Untuk memahami bagaimana konsumen benar-benar membuat keputusan pembelian, pemasar harus mengidentifikasi siapa yang mengambil keputusan dan mempunyai masukan dalam keputusan pembelian ; orang bisa menjadi pemicu, pihak yang mempengaruhi, mengambil keputusan, pembeli, atau pengguna. Kampanye pemasaran yang berbeda dapat ditargetkan kepada masing-masing jenis orang. Proses pemebelian umum terdiri dari urutan kejadian berikut : pengenalan masalah, pencarian informasi, evaluasi alternative, keputusan pembelian, dan perilaku pasca pembelian. Tugas pemasar adalah memahami perilaku pada setiap tahap. Sikap orang lain, faktor situasional yang tidak diantisipasi, dan risiko anggapan, semuanya mempengaruhi keputusan untuk membeli, dan juga tingkat kepuasan produk pasca pembelian konsumen, pemakaian dan penyingkiran, dan tindakan dari pihak perusahaan.

\section{Citra Merek}

Sebagaimana diketahui bahwa merek merupakan pembeda antar satu produk dengan produk lainnya. Kita menyimpan memori dibenak kita akan suatu produk dengan isi mengenai mengenal produk tersebut, bukan tentang produk-produk apa yang fungsi dan kegunaanya sama. Merek (brand) telah menjadi elemen yang sangat krusial yang berkontribusi terhadap kesuksesan sebuah organisasi pemasaran, baik perusahaan bisnis maupun penyedia jasa, organisasi lokal maupun global.

Menurut UU Merek No.15 Tahun 2001 Pasal 1 Ayat 1: Merek adalah tanda yang berupa gambar, nama kata, huruf-huruf, angka-angka, susunan warna atau kombinasi dari unsur-unsur tersebut yang memiliki daya pembeda dan digunakan dalam kegiatan perdagangan barang dan jasa.

Definisi ini memiliki kesamaan dengan definisi versi American Marketing Association yang menekankan peranan merek sebagai identifier dan differentiation.

Aaker dan Joachimstahler (2007 : 51), mengemukakan bahwa "merek memiliki karakteristik yang lebih luas dari pada produk yaitu citra pengguna produk, asosiasi perusahaan, 
symbol-simbol, dan hubungan merek/pelanggan".

Merek sangat bermanfaat bagi konsumen dan produsen. Menurut Kotler (2009 : 38), bagi produsen merek berperan penting sebagai :

a. Sarana identifikasi untuk memudahkan proses penanganan atau pelacakan produk bagi perusahaan.

b. Bentuk proteksi hukum terhadap fitur atau aspek produk yang unik.

c. Signal tingkat kualitas bagi para pelanggan yang puas, sehingga mereka bisa dengan mudah memilih dan membelinya lagi di lain waktu.

d. Sarana menciptakan asosiasi dan makna unik yang membedakan produk dari para pesaing.

e. Sumber keunggulan kompetitif, terutama melalui perlindungan hukum, loyalitas pelanggan, dan citra unik yang berbentuk dalam benak konsumen.

f. Sumber financial returns terutama menyangkut pendapatan masa depan.

Sedangkan bagi konsumen, merek berfungsi sebagai identifikasi sumber produk, penetapan tanggung jawab pada pemanufaktur atau distributor tertentu, pengurangan resiko, penekanan biaya pencarian internal dan eksternal, janji dan ikatan khusus dengan produsen, alat simbolis yang memproyeksi citra diri,dengan signal kualitas.

Menurut Palmer (2009 : 184), bahwa merek adalah penting didalam membimbing pembeli ketika memilih antara pelayanan yang bersaing namun kelihatan serupa.

Menurut Kotler (2009: 460), yaitu :
Merek adalah suatu nama, istilah, tanda, lambang, rancangan, atau kombinasi dari hal-hal tersebut, yang dimaksudkan untuk mengidentifikasi barang atau jasa dari seorang atau sekelompok penjual dan untuk membedakannya dari produk pesaing.

Kadang kita tidak dapat membedakan sesuatu secara jelas antara identitas dan citra. Untuk membedakannya, maka akan kita lihat pengertian masing-masing menurut Kotler (2009:259) : " Identitas adalah berbagai cara yang diarahkan perusahaan untuk mengidentifikasikan dirinya atau memposisikan produknya".

Sedangkan citra / image, yaitu : "Citra adalah persepsi masyarakat terhadap perusahaan atau produknya". Maka jelas jika, " Brand Image" atau citra merek adalah bagaimana suatu merek mempengaruhi persepsi, pandangan masyarakat atau konsumen terhadap perusahaan atau produknya.

Pengertian Brand Image (Keller, 2009:166) bahwa:

1. Anggapan tentang merek yang direfleksikan konsumen yang berpegang pada ingatan konsumen.

2. Cara orang berpikir tentang sebuah merek secara abstrak dalam pemikiran mereka, sekalipun pada saat mereka memikirkannya, mereka tidak berhadapan langsung dengan produk. Elemen - elemen dari merek (Kotler) adalah: nama, logo, symbol, desain, slogan, dan kemasan.

Beberapa kriteria yang harus diperhatikan dalam pemilihan elemen merek:

1. Mudah diingat, artinya elemen merek yang dipilih hendaknya 
yang mudah diingat, dan disebut/diucapkan. Simbol, logo, nama yang digunakan hendaknya menarik, unik sehingga menarik perhatian masyarakat untuk diingat dan dikonsumsi.

2. Memiliki makna, artinya elemen merek hendaknya mengandung sebuah makna maupun penjelasan/ deskripsi dari produk. Diharapkan makna ini dapat mempengaruhi konsumen untuk mengkonsumsi produk tersebut. Deskripsi makna yang terkandung dapat berupa :

a. informasi umum tentang kategori dan isi dari produk

b. informasi tentang komposisi penting yang ditonjolkan produk dan manfaat dari produk.

3. Menarik dan lucu, artinya pendekatan lain untuk menarik perhatian konsumen adalah dengan variasi elemen merek yang unik, lucu, pemilihan elemen yang kaya akan visualisasi dan imajinasi. Dalam hal ini yang ditonjolkan adalah desain yang menarik dan lucu.

Sebuah brand (merek) membutuhkan image (citra) untuk mengkomunikasikan kepada khalayak dalam hal ini pasar sasarannya tentang nilai-nilai yang terkandung didalamnya. Bagi perusahaan citra berarti persepsi masyarakat terhadap jati diri perusahaan. Persepsi ini didasarkan pada apa yang masyarakat ketahui atau kira tentang perusahaan yang bersangkutan. Oleh karena itulah perusahaan yang memiliki bidang usaha yang sama belum tentu memiliki citra yang sama pula dihadapan orang atau konsumen. Citra merek menjadi salah satu pegangan bagi konsumen dalam mengambil keputusan penting.

Brand Image (citra merek) dapat dianggap sebagai jenis asosiasi yang muncul dalam benak konsumen ketika mengingat suatu merek tertentu. Asosiasi tersebut secara sederhana dapat muncul dalam bentuk pemikiran atau citra tertentu yang dikaitkan dengan suatu merek, sama halnya ketika kita berfikir tentang orang lain. Asosiasi ini dapat dikonseptualisasi berdasarkan jenis, dukungan, keunggulan, kekuatan, dan keunikan.

Kadang kita tidak dapat membedakan sesuatu secara jelas antara identitas dan citra. Untuk membedakannya, maka akan kita lihat pengertian masing-masing menurut Kotler (2007:259) : “ Identitas adalah berbagai cara yang diarahkan perusahaan untuk mengidentifikasikan dirinya atau memposisikan produknya".

Sedangkan citra / image, yaitu : "Citra adalah persepsi masyarakat terhadap perusahaan atau produknya". Maka jelas jika, " Brand Image" atau citra merek adalah bagaimana suatu merek mempengaruhi persepsi, pandangan masyarakat atau konsumen terhadap perusahaan atau produknya.

Pengertian Brand Image (Keller, 2003:166) bahwa:

3. Anggapan tentang merek yang direfleksikan konsumen yang berpegang pada ingatan konsumen.

4. Cara orang berpikir tentang sebuah merek secara abstrak dalam pemikiran mereka, sekalipun pada saat mereka memikirkannya, mereka tidak berhadapan langsung dengan 
produk. Elemen - elemen dari merek (Kotler) adalah: nama, logo, symbol, desain, slogan, dan kemasan.

Beberapa kriteria yang harus diperhatikan dalam pemilihan elemen merek:

3. Mudah diingat, artinya elemen merek yang dipilih hendaknya yang mudah diingat, dan disebut/diucapkan. Simbol, logo, nama yang digunakan hendaknya menarik, unik sehingga menarik perhatian masyarakat untuk diingat dan dikonsumsi.

4. Memiliki makna, artinya elemen merek hendaknya mengandung sebuah makna maupun penjelasan/ deskripsi dari produk. Diharapkan makna ini dapat mempengaruhi konsumen untuk mengkonsumsi produk tersebut. Deskripsi makna yang terkandung dapat berupa :

a. informasi umum tentang kategori dan isi dari produk

b. informasi tentang komposisi penting yang ditonjolkan produk dan manfaat dari produk.

3. Menarik dan lucu, artinya pendekatan lain untuk menarik perhatian konsumen adalah dengan variasi elemen merek yang unik, lucu, pemilihan elemen yang kaya akan visualisasi dan imajinasi. Dalam hal ini yang ditonjolkan adalah desain yang menarik dan lucu.

Sebuah brand (merek) membutuhkan image (citra) untuk mengkomunikasikan kepada khalayak dalam hal ini pasar sasarannya tentang nilai-nilai yang terkandung didalamnya. Bagi perusahaan citra berarti persepsi masyarakat terhadap jati diri perusahaan. Persepsi ini didasarkan pada apa yang masyarakat ketahui atau kira tentang perusahaan yang bersangkutan. Oleh karena itulah perusahaan yang memiliki bidang usaha yang sama belum tentu memiliki citra yang sama pula dihadapan orang atau konsumen. Citra merek menjadi salah satu pegangan bagi konsumen dalam mengambil keputusan penting.

Brand Image (citra merek) dapat dianggap sebagai jenis asosiasi yang muncul dalam benak konsumen ketika mengingat suatu merek tertentu. Asosiasi tersebut secara sederhana dapat muncul dalam bentuk pemikiran atau citra tertentu yang dikaitkan dengan suatu merek, sama halnya ketika kita berfikir tentang orang lain. Asosiasi ini dapat dikonseptualisasi berdasarkan jenis, dukungan, keunggulan, kekuatan, dan keunikan.

Membangun Brand Image yang positif dapat dicapai dengan program marketing yang kuat terhadap produk tersebut, yang unik dan memiliki kelebihan yang ditonjolkan, yang membedakannya dengan produk lain. Kombinasi yang baik dari elemenelemen yang mendukung (seperti yang telah dijelaskan sebelumnya) dapat menciptakan Brand Image yang kuat bagi konsumen. Faktor-faktor pendukung terbentuknya Brand Image dalam keterkaitannya dalam asosiasi merek (Keller, 2003:167) :

1. Keunggulan asosiasi merek (Favorability of brand association)

Salah satu faktor pembentuk

Brand Image adalah keunggulan produk, dimana produk tersebut unggul dalam persaingan.Karena keunggulan kualitas (model dan kenyamanan) dan ciri khas itulah yang menyebabkan 
suatu produk mempunyai daya tarik tersendiri bagi konsumen.Favorability of brand association adalah asosiasi merek dimana konsumen percaya bahwa atribut dan manfaat yang diberikan oleh merek akan dapat memenuhi atau memuaskan kebutuhan dan keinginan mereka sehingga mereka membentuk sikap positif terhadap merek. Sebuah program marketing dikatakan sukses apabila keseluruhan program mencerminkan kreativitas yang memberikan kepercayaan kepada konsumen, terhadap merek yang membawa banyak keuntungan dan dapat memuaskan keinginan dan kebutuhan para konsumen dimana hal tersebut adalah tindakan yang dipandang positif secara keseluruhan dan merupakan tindakan yang biasa dilakukan. Sehingga keinginan dan kebutuhan konsumen dapat dipuaskan dengan cara memberikan keuntungan dan kepuasan lebih ke konsumen.

Ada beberapa cara dalam memenuhi keunggulan asosiasi merek menurut Russel dan Lane (1995), yaitu :Kebutuhan, Keinginan, dan Permintaan

Dasar pemikiran pemasaran dimulai dari kebutuhan dan keinginan manusia.Adalah penting untuk membedakan kebutuhan, keinginan, dan permintaan. Maslow menyatakan adanya hirarki kebutuhan yang terdiri dari lima tingkatan, yang dimulai dari kebutuhan yang paling utama yaitu kebutuhan fisik seperti makan, minum, pakaian, dan tempat tinggal sebagai kebutuhan yang harus dipenuhi segera, dan kebutuhan lanjutan yang terdiri dari kebutuhan akan rasa aman, bersosialisasi, penghargaan diri dan aktualisasi diri.

Menurut Kotler (1997, 8), Keinginan (wants) adalah hasrat akan pemuas kebutuhan yang spesifik. Keinginan manusia terus dibentuk dan diperbaharui oleh kekuatan dan lembaga sosial.

$\begin{array}{lrr}\text { Menurut John } & \text { E } & \begin{array}{r}\text { Kennedy } \\ \text { maketing }\end{array} \\ \text { dalam } & \text { bukunya } & \begin{array}{r}\text { mammunication } \\ \text { commatakan }\end{array}\end{array}$
permintaan adalah alasan sebuah barang diproduksi dalam jumlah tertentu.Sebuah permintaan muncul pada suatu kebutuhan muncul dan dirasakan untuk segera dipenuhi, dan terkadang permintaan ini belum terpenuhi oleh jumlah produk yang beredar di pasar.

a. Produk

Definisi produk menurut W.J Stanton $(2005,139)$ yang dikutip oleh Buchari Alma adalah seperangkat atribut baik berwujud maupun tidak berwujud, termasuk didalamnya masalah warna, harga, nama baik pabrik, nama baik took yang menjual (pengecer), dan pelayanan pabrik serta pelayanan pengecer yang diterima oleh pembeli guna memuaskan kebutuhannya.

b. Nilai, Biaya, dan Kepuasan

Nilai (value) adalah perkiraan konsumen atas seluruh kemampuan produk untuk memuaskan kebutuhannya. Atau dengan kata lain nilai adalah pemenuhan tuntutan pelanggan dengan biaya perolehan, pemilikan, dan penggunaan yang terendah.

\section{Kekuatan asosiasi merek (Strength of brand association)}

Strength of brand association adalah kekuatan asosiasi merek tergantung pada bagaimana informasi masuk kedalam ingatan konsumen dan bagaimana proses bertahan sebagai bagian dari citra merek. Kekuatan asosiasi merek ini merupakan fungsi dari jumlah pengolahan informasi yang 
diterima pada proses ecoding. Ketika seorang konsumen secara aktif menguraikan arti informasi suatu produk atau jasa maka akan tercipta asosiasi yang semakin kuat pada ingatan konsumen. Pentingnya asosiasi merek pada ingatan konsumen tergantung pada bagaimana suatu merek tersebut dipertimbangkan.

Dalam membuat kekuatan asosiasi merek dapat melalui bauran promosi komunikasi pemasaran (promotion mix).Menurut Stanton yang dikutip oleh Saladin (2006, 172), "bauran promosi adalah kombinasi dari penjualan tatap muka, periklanan, promosi penjualan, publisitas dan hubungan yang membantu pencapaian tujuan penjualan".

Contoh membangun kepopuleran merek dengan strategi komunikasi melalui periklanan.Setiap merek yang berharga mempunyai jiwa, suatu kepribadian khusus adalah kewajiban mendasar bagi pemilik merek untuk dapat mengungkapkan, mensosialisasikan jiwa / kepribadian tersebut dalam satu bentuk iklan, ataupun bentuk kegiatan promosi dan pemasaran lainnya. Hal itulah yang akan terus menerus yang menjadi penghubung antara produk / merek dengan konsumen. Dengan demikian merek tersebut akan cepat dikenal dan akan tetap terjaga ditengah-tengah maraknya persaingan. Membangun popularitas sebuah merek tidaklah mudah, namun demikian popularitas adalah salah satu kunnci yang dapat membentuk Brand Image.

\section{a. Periklanan}

Semua bentuk penyajian non personal dan promosi ide, barang atau jasa yang memerlukan pembayaran. Dalam beriklan diperlukan sebuah komunikasi yang tepat dan efektif baik itu isi pesan, media sehingga akan berdampak pada konsumen yang melihatnya.

b. Promosi penjualan

Berbagai kiat insentif yang beragam, kebanyakan jangka pendek untuk mendorong keinginan konsumen mencoba atau membeli suatu produk atau jasa.Promosi penjualan cenderung memiliki efek yang singkat sebagai upaya menstimulasi tekanan pada sikap pembelian konsumen.

c. Hubungan masyarakat dan publisitas

Berbagai program yang dirancang untuk mempromosikan dan atau melindungi citra perusahaan atau produk individualnya.Fungsi dari hubungan masyarakat adalah mengidentifikasi area komunitas yang berkaitan dengan bisnis perusahaan dan membina hubungan baik dengan menciptakan pengembangan komunitas melalui sebuah program untuk mendapat pengertian dan penerimaan dari publik.

d. Penjualan secara pribadi

Interaksi langsung dengan satu calon pembeli atau lebih untuk melakukan presentasi, menjawab Pernyataan, dan menerima pesanan.Dengan penjualan secara pribadi mampu mendekatkan pelanggan dengan penjual lewat penggunaan jalur-jalur distribusi barang dan produk yang ada.

e. Pemasaran langsung

Penggunaan surat, telepon, faksimil, e-mail, dan alat penghubung nonpersonal lain untuk berkomunikasi secara lanmgsung dengan atau mendapatkan tanggapan langsung dari pelanggan tertentu dan calon pelanggan.

3. Keunikan asosiasi merek (Uniqueness of brand association) 
Uniqueness of brand association adalah asosiasi terhadap suatu merek mau tidak mau harus terbagi dengan merek-merek lain. Oleh karena itu, harus diciptakan keunggulan bersaing yang dapat dijadikan alasan bagi konsumen untuk memilih suatu merek tertentu.Dengan memposisikan merek lebih mengarah kepada pengalaman atau keuntungan diri dari image produk tersebut. Dari perbedaan yang ada, baik dari produk, pelayanan, personil, dan saluran yang diharapkan memberikan perbedaan dari pesaingnya. Yang dapat memberikan keuntungan bagi produsen dan konsumen. Atau dengan kata lain merupakan keunikan-keunikan yang dimiliki oleh produk/merek tersebut.

Dalam membuat keunikan asosiasi merek dapat dilakukan dengan melakukan diferensiasi merek dengan merek lain. Menurut Philip Kotler (1997, 251) diferensiasi adalah tindakan merancang satu set perbedaan yang berarti untuk membedakan penawaran perusahaan dari penawaran pesaing. Suatu perusahaan harus mencoba mengidentifikasi cara-cara spesifik yang dapat mendiferensiasikan produknya untuk mencapai keunggulan kompetitif.

Menurut Kotler (1997), ada lima variabel dalam suatu penawaran pasar, yaitu:

a. Diferensiasi produk

Diferensiasi produk fisik menyerupai garis. Diujung yang satu merupakan produk yang sangat standarisasi yang memungkinkan sedikit variasi, sedangkan diujung yang lain adalah produk dengan diferensiasi tinggi. Variabel dari diferensiasi produk yaitu keistimewaan, kinerja, kesesuaian, daya tahan, keandalan, mudah diperbaiki, gaya dan rancangan.

b. Diferensiasi pelayanan Jika produk fisik tidak mudah di deferensiasi, kunci keberhasilan dalam persaingan sering terletak pada penambahan pelayanan yang menambah nilai serta meningkatkan kualitasnya.Pembeda pelayanan utama adalah kemudahan pemesanan, pengiriman, pemasangan, pelatihan pelanggan, konsultasi langganan, pemeliharaan dan perbaikan.Variabel dari diferensiasi pelayanan adalah kemudahan pemesanan, pelatihan pelanggan, konsultasi pelanggan, pemeliharaan dan perbaikan keramahan.

c. Diferensiasi personil

Perusahaan dapat memperoleh keunggulan kompetitif yang kuat dengan memperkerjakan dan melatih orang-orang yang lebih baik daripada pesaing mereka.Personil yang terlatih lebih baik menunjukkan enam karakteristik yaitu kemampuan, kesopanan, kreadibilitas, dapat diandalkan, cepat tanggap, komunikasi. d. Diferensiasi citra

Menurut Philip Kotler (1997, 259) Citra adalah persepsi masyarakat terhadap perusahaan atau produknya.Variabel dari diferensiasi citra adalah lambang, media tertulis dan audiovisual, suasana, dan acaraacara.

Dari faktor-faktor ini akan menentukan brand image. Brand Image yang positif akan dicapai apabila dari ketiga faktor pembentuk brand image ini terdapat keserasian dengan nilai rata-rata. Merek bervariasi dalam hal kekuatan dan nilai yang dimilikinya dipasar.

\section{Kerangka Pemikiran}




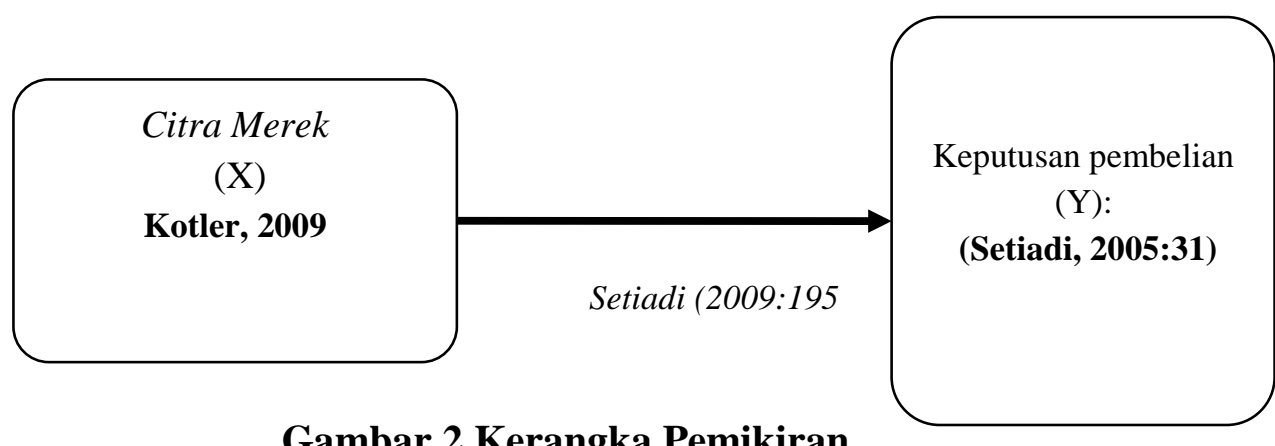

\section{Gambar 2.Kerangka Pemikiran}

\section{Hipotesis}

Berdasarkan atas kerangka
pemikiran dan identifikasi
masalah,serta paradigma penelitian
maka penulis mengajukan hipotesis :

Ho Tidak Terdapat pengaruh citra merek (brand image) terhadap keputusan pembelian mobil Toyota Kijang Avanza pada Auto 2000 Cabang Bandung

H1 Terdapat pengaruh citra merek (brand image) terhadap keputusan pembelian mobil Toyota Kijang Avanza pada Auto 2000 Cabang Bandung.

\section{METODE PENELITIAN}

Metode penelitian ini menggunakan analisis deskriptif dan verifikatif.penelitian deskriptif adalah penelitian yang dilakukan untuk mengetahui nilai variabel mandiri, baik satu atau lebih (independen) tanpa membuat perbandingan, atau atau menghubungkan dengan variabel lain (Sugiyono, 2008 : 11) . Sedangkan penelitian verifikatif digunakan untuk membuktikan adanya hubungan citra merek (brand image) terhadap keputusan pembelian mobil Toyota Kijang Avanza pada Auto 2000 Cabang Bandung (Mochamad , 2004 : 63)..Pada penelitian ini dilaksanakan melalui pengumpulan data di lapangan, maka metode penelitian yang digunakan adalah metode survey, yaitu informasi dari sebagian populasi dikumpulkan secara langsung di tempat kejadian dengan tujuan untuk mengetahui pendapat dari sebagian populasi terhadap aspek yang sedang diteliti (Nur Indriantoro, 2003 : 26).

\section{Teknik Analisis Data \\ Uji Validitas}

Validitas merupakan derajat ketepatan antara data yang terjadi pada objek penelitian dengan daya yang dapat dilaporkan oleh peneliti. Terdapat dua macam validitas penelitian, yaitu validitas internal yang berkenaan dengan derajat akurasi desain penelitian dengan hasil yang dicapai, dan validitas eksternal yang berkenaan dengan derajat akurasi apakah hasil penelitian dapat digeneralisasikan atau diterapkan pada populasi di mana sampel tersebut diambil (Sugiyono, 2008: 267). Untuk pengujian validitas tiap butir digunakan analisis item, yaitu mengkorelasikan skor tiap butir dengan skor total yang merupakan jumlah tiap skor butir. Selanjutnya nilai korelasi Product Moment hasil perhitungan dibandingkan dengan $r$ tabel, jika $r$ hitung lebih besar dari $\mathrm{r}$ tabel berarti korelasi Product Moment untuk tiap 
butir pernyataan adalah valid". Moh. Nazir (2003 : 133) menyatakan bahwa :

Jika reliabilitas dan validitas tidak diketahui, maka akibatnya menjadi fatal dalam memberikan kesimpulan ataupun dalam memberikan alasan terhadap hubungan-hubungan antar variabel. Bahkan secara luas, reliabilitas dan validitas mencakup mutu seluruh proses pengumpulan data sejak konsep disiapkan sampai kepada data siap untuk dianalisis.

Bila $r_{\text {hitung }} \geq r_{\text {tabel }}$ pada $\alpha=0.05$ berarti data tersebut signifikan (valid) dan layak digunakan dalam pengujian hipotesis penelitian. Sebaliknya bila $\mathrm{r}_{\text {hitung }}<\mathrm{r}_{\text {tabel }}$ berarti data tersebut tidak signifikan (tidak valid) dan tidak dapat diikutsertakan dalam pengujian hipotesis penelitian.

\section{Uji Reabilitas}

Setelah dilakukan pengujian validitas, maka langkah selanjutnya adalah melakukan pengujian reliabilitas. Sugiyono (2008 : 130) menyatakan bahwa pengujian reliabilitas instrumen dapat dilakukan secara eksternal maupun internal. Secara eksternal pengujian dapat dilakukan dengan test-retest (stability), equivalent, dan gabungan keduanya. Secara internal reliabilitas instrumen dapat diuji dengan menganalisis konsistensi butir-butir yang ada dengan teknik tertentu.

Dalam penelitian ini, pengujian reliabilitas instrumen menggunakan internal consistency, dimana instrumen dicobakan sekali saja. Data yang diperoleh kemudian dianalisis, dalam hal ini digunakan teknik belah dua dari Spearman Brown (Split half).

\section{Analisis Regresi Berganda}

\section{Koefisien determinasi}

Koefisien determinasi $\left(\mathrm{R}^{2}\right)$ pada intinya mengukur seberapa jauh kemampuan model dalam menerangkan variasi variabel dependen. Nilai koefisien determinasi adalah diantara nol dan satu. Nilai $\left(\mathrm{R}^{2}\right)$ yang kecil berarti kemampuan variabelvariabel independen dalam menjelaskan variasi variabel dependen memberikan hampir semua informasi yang dibutuhkan untuk memprediksi variasi variabel dependen (Imam Ghazali, 2002 : 45).

Untuk mengetahui besarnya koefisien determinasi $\left(\mathrm{R}^{2}\right)$ atau besarnya pengaruh antara variabel independenterhadap variabel dependendigunakan rumus sebagai berikut :

$$
R^{2}=\frac{\beta_{1}\left(x^{\prime} y\right)}{\left(y^{\prime} y\right)}
$$

Dimana analisis koefisien
determinasi ini adalah untuk mengetahui besarnya pengaruh variabel independen terhadap variabel dependen. Secara verbal $\mathrm{R}^{2}$ digunakan untuk mengukur proporsi atau presentasi variasi total dalam variabel dependen (Y) yang dijelaskan oleh variabel independen (X). Adapun dua sifat dari $\mathrm{R}^{2}$, yaitu :

$$
\text { 1. Merupakan besaran non }
$$

negatif

$$
\text { 2. Besarnya adalah } 0 \leq \mathrm{R}^{2} \leq 1
$$

\section{Persamaan Regresi}

Persamaan regresi digunakan untuk mengetahui elastisitas variabel independen terhadap variabel dependennya. Persamaan ini digunakan untuk melihat seberapa besar 
perubahan pada variabel independen yang akan mempengaruhi variabel dependennya.

Adapun persamaan yang akan digunakan adalah sebagai berikut : dibandingkan dari pendidikan lainnya.

- status responden paling banyak telah menikah dengan presentase $82 \%$ dibandingkan dengan responden vang belum kawin.

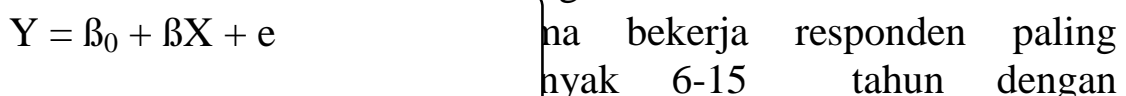
presentase $60 \%$ dibandingkan

Ket $: \mathrm{Y}=$ Keputusan Pembelian; $\mathrm{X}=$ Brand Image; $\beta_{0}=$ Konstanta; $B \mathrm{i}=$ Koefisien regresi, $\mathrm{n}=1$,

$$
\mathrm{e}=\text { Epsilon/Variabel kontrol }
$$

(Sugiyono,2008)

Arti koefisien $\beta$ adalah jika nilai $\beta$ positif (+) hal tersebut menunjukkan hubungan yang searah antara variabel bebas dengan variabel tidak bebas. Dengan kata lain peningkatan/penurunan variabel bebas akan disertai dengan peningkatan/penurunan variabel tidak bebas.

Sedangkan jika nilai $\beta$ negatif () hal tersebut menunjukkan hubungan yang berlawanan antara variabel bebas dengan variabel tidak bebas. Setiap peningkatan variabel bebas akan diikuti dengan penurunan variabel tidak bebas, dan begitupun sebaliknya.

\section{ANALISIS \\ PEMBAHASAN}

DATA

\section{Profil Responden}

- jenis kelamin responden yang paling banyak adalah pria dengan presentase $93,9 \%$ dibandingkan dengan responden wanita.

- responden dengan usia $36-45$ Tahun berjumlah 94 orang atau $41,3 \%$, lebih banyak dari usia responden lainnya.

- responden yang memiliki pendidikan D1-D3 paling banyak dengan presentase dengan lama bekerja responden yang lain.

Uji Validitas

Tabel 3. Hasil Validitas Item

Variabel Citra Merek (X1)

\begin{tabular}{|c|c|c|c|c|}
\hline $\begin{array}{c}\text { No } \\
\text { Item }\end{array}$ & $\begin{array}{c}\text { Simbol } \\
\text { Item }\end{array}$ & r Hitung & r Kritis & Keterangan \\
\hline 1 & X1_1 & 0,926 & 0,273 & Valid \\
\hline 2 & X1_2 & 0,897 & 0,273 & Valid \\
\hline 3 & X1_3 & 0,899 & 0,273 & Valid \\
\hline 4 & X1_4 & 0,920 & 0,273 & Valid \\
\hline 5 & X1_5 & 0,920 & 0,273 & Valid \\
\hline 6 & X1_6 & 0,813 & 0,273 & Valid \\
\hline 7 & X1_7 & 0,725 & 0,273 & Valid \\
\hline 8 & X1_8 & 0,688 & 0,273 & Valid \\
\hline 9 & X1_9 & 0,683 & 0,273 & Valid \\
\hline 10 & X1_10 & 0,929 & 0,273 & Valid \\
\hline 11 & X1_11 & 0,676 & 0,273 & Valid \\
\hline 12 & X1_12 & 0,473 & 0,273 & Valid \\
\hline
\end{tabular}

Sumber : Lampiran Uji Validitas

Berdasarkan Tabel di atas terlihat bahwa semua item pertanyaan valid, Sehingga 12 pernyataan pada kuesioner dalam penelitian ini layak untuk diikutsertakan dalam penelitian ini

Tabel 4.Hasil Validitas Item Variabel Keputusan Pembelian (Y)

\begin{tabular}{|c|c|c|c|c|}
\hline $\begin{array}{c}\text { No } \\
\text { Item }\end{array}$ & $\begin{array}{c}\text { Simbol } \\
\text { Item }\end{array}$ & r Hitung & r Kritis & Keterangan \\
\hline 1 & Y_1 & 0,835 & 0,273 & Valid \\
\hline 2 & Y_2 & 0,360 & 0,273 & Valid \\
\hline
\end{tabular}




\begin{tabular}{|c|c|c|c|c|}
\hline 3 & Y_3 & 0,593 & 0,273 & Vwiedndaknya Auto 2000 Cabang \\
\hline 4 & Y_4 & 0,356 & 0,273 & VBaindung lebih memperhatikan \\
\hline 5 & Y_5 & 0,285 & 0,273 & VAlfpuasan lagi pada konsumen agar \\
\hline
\end{tabular}
terlihat bahwa semua item pertanyaan valid, Sehingga 5 pernyataan pada kuesioner dalam penelitian ini layak untuk diikutsertakan dalam penelitian ini

Untuk peneliti lain hendaknya memcari variabel lain yang mempengaruhi keputusan pembelian.

\section{DAFTAR PUSTAKA}

Daft.2003. Manajemen Edisi

\section{UjiReliabilitas}

Tabel 5. Hasil Pengujian Reliabilitas

\begin{tabular}{|c|c|c|c|}
\hline Variabel & Reliabilitas & r Kritis & Keterangan \\
\hline $\mathrm{X}$ & 0,927 & 0,600 & Reliabel \\
\hline $\mathrm{Y}$ & 0,722 & 0,600 & Reliabel \\
\hline \multicolumn{4}{|c}{ Pumber $:$ data diolah } \\
\hline
\end{tabular}

2.Yogyakarta : BPFE

Gujarati , Damodar N. 2003. Basic Econometrics Fourth Edition".The Mc. Growth Hill compnies Inc. New York.

Sumber : data diolah

$$
\text { Prentile Hall: New York }
$$

Berdasarkan hasil pengujian reliabilitas semua variabel mempunyai reliabilitas yang baik karena memiliki $r$ hitung yang lebih besar dari $\mathrm{r}_{\text {Tabel }}$ seperti terlihat pada Tabel 4.8 dengan demikian, setiap pernyataan pada kuisioner tersebut dapat dianalisa lebih lanjut.

\section{SIMPULAN DAN SARAN}

Citra merek Mobil Toyota Kijang Avanza Pada Auto 2000 Cabang Bandung cukup baik menurut baik menurut persepsi konsumen

Keputusan pembelian Mobil Toyota Kijang Avanza Pada Auto 2000 Cabang Bandung cukup baik menurut persepsi konsumen

Citra merek berpengaruh signifikan terhadap keputusan pembelian Mobil Toyota Kijang Avanza Pada Auto 2000 Cabang Bandung.

Hendaknya Auto 2000 Cabang Bandung memperhatikan dan mempertahankan citra merek karena dalam penelitan ini citra merek Lewis dkk. 2004. Management. Prentile Hall: new York

Hani Handoko. 2003. Manajemen Edisi 2.Yogyakarta : BPFE

Imam Gozali . 2002. Aplikasi Analisis Multivariate dengan program SPSS. Semarang : Badan Penerbit Universitas Diponegoro.

Kotler, Philip dan Kelller KL.Diterjemahkan Oleh Benyamin Molan.2008. Manajemen Pemasaran Jild 1 Edisi 12. PT. Indeks

Kotler , Philip. 2010 Manajemen Pemasaran, jilid 1, Edisi Indonesia, Edisi Milenium, Edisi Kesepuluh, Jakarta : Penerbit PT. Prenhallindo

Nur Indiantoro dan Bambang Supomo, 2009. "metode Penelitian Bisnis". Penerbit BPFE, Yogyakarta

Nurul Rizki Fachira. 2012. Pengaruh Brand Image Terhadap Keputusan Pembelian Mobil Merek Pajero Sport Pada PT.Bosowa Berlian Motor 
Ristiyanti Prasetijo dan Jhon J.O.I Ihalauw. 2005. Perilaku Konsumen .Yogyakarta : Andi. Rizki Nurafdal

Mustikarillah.2011.Pengaruh dari Brand Image Terhadap Pengambilan Keputusan Pembelian Mobil Toyota Rush.

Sugiyono .2008.Metode Penelitian Bisnis. Bandung : CV. Alfabeta 